\title{
INFLUENCE OF INCUBATION PERIOD, TEMPERATURE AND DIFFERENT PHOSPHATE LEVELS ON PHOSPHATE ADSORPTION IN SOIL
}

\author{
${ }^{1}$ Rajput, A., ${ }^{1,2}$ Q.A. Panhwar, ${ }^{3}$ U.A. Naher, ${ }^{1}$ S. Rajput, ${ }^{3}$ E. Hossain and ${ }^{2}$ J. Shamshuddin \\ ${ }^{1}$ Soil Chemistry Section, Agriculture Research Institute, Tandojam, Pakistan \\ ${ }^{2}$ Department of Land Management, Faculty of Agriculture, Universiti Putra Malaysia, 43400 Serdang, Malaysia \\ ${ }^{3}$ Bangladesh Rice Research Institute, Gazipur 1701, Bangladesh
}

Received 2014-01-27; Revised 2014-01-28; Accepted 2014-02-13

\begin{abstract}
Phosphorus (P) is the most important element after nitrogen but $\mathrm{P}$ sorption properties are poorly documented in many soils. In this study, $\mathrm{P}$ sorption capacity in relation to incubation period and temperature under various $\mathrm{P}$ levels were determined for two different soil series (Rustam and Miani). Phosphorus was added at 5, 10, 25, 50, 100, 250, 500 and $1000 \mu \mathrm{g} \mathrm{g}^{-1}$ to the soils and incubated for the period of $1,3,7,15,30$ and 60 days at 25 and $35 \pm 1^{\circ} \mathrm{C}$ temperatures. Phosphorus sorption was significantly influenced by the temperature, added $\mathrm{P}$ and incubation period. Clay content has major influence on $\mathrm{P}$ sorption. Rustum Series adsorbed more P than that of Miani Series. The P sorption was faster at high temperature $\left(35^{\circ} \mathrm{C}\right)$. At the end of period in the Rustum Series with added 2.5 and $1000 \mu \mathrm{g} \mathrm{g}^{-1} \mathrm{P}$ level, $\mathrm{P}$ sorption were found 0.7 and $943 \mu \mathrm{g} \mathrm{g}{ }^{-1}$, respectively, at $25 \pm 1^{\circ} \mathrm{C}$ temperature, whereas at $35 \pm 1{ }^{\circ} \mathrm{C}$ temperature the respective $\mathrm{P}$ sorption for same $\mathrm{P}$ levels were 1.8 and $987.0 \mu \mathrm{g} \mathrm{g}^{-1}$. In the Miani Series at $25 \pm 1^{\circ} \mathrm{C}$ temperature, $\mathrm{P}$ sorption was 0.7 and $941 \mu \mathrm{g} \mathrm{g}-1$, while at the temperature of $35 \pm 1^{\circ} \mathrm{C}$, $\mathrm{P}$ sorption were 1.0 and $986 \mu \mathrm{g} \mathrm{g}^{-1}$ soil. Increasing P levels, temperature and incubation, resulted in higher P sorption. Hence, high clay in combination with calcium carbonate contents enhanced $\mathrm{P}$ adsorption, while high organic matter and high native soil $\mathrm{P}$ resulted in lesser $\mathrm{P}$ adsorption.
\end{abstract}

Keywords: Incubation, Clay Content, Phosphorus, Soil Series, Sorption, Temperature

\section{INTRODUCTION}

Phosphorus is most important element for natural ecosystems throughout the world (Onweremadu, 2007). Its availability is limited by fixation in soil. Soil $\mathrm{pH}$ is one of the important factors affecting $\mathrm{P}$ retention in soils. $\mathrm{P}$ sorption reactions with $\mathrm{Fe}$ and $\mathrm{Al}$ occur at $\mathrm{pH}<7$, while at $\mathrm{pH}>7.0 \mathrm{Ca}$ and $\mathrm{Mg}$ ions in the presence of carbonates help precipitate added $\mathrm{P}$ (Bubba et al., 2001). P has high affinity for mineral surfaces and thus, it is often the least available nutrient to plants. Efficiency of the applied $\mathrm{P}$ fertilizer is only about $20 \%$ under alkaline calcareous soil conditions. P requirement of crops depends mainly on imported $\mathrm{P}$ fertilizer, which is expensive. The bioavailability of $\mathrm{P}$ is essential in understanding the processes involved in its sorption because high quantity $(>90 \%)$ of applied $\mathrm{P}$ in soil can be fixed after its application. Sorption of $\mathrm{P}$ is a process in which readily soluble $\mathrm{P}$ is changed to less soluble forms by reacting with inorganic or organic compound of the soil so that $\mathrm{P}$ becomes immobilized and is reduced for plants uptake (Khan et al., 2007).

Clay content has a major effect on $\mathrm{P}$ retention in soil (Devau et al., 2010). Likewise, calcium carbonate in soils affects $\mathrm{P}$ fixation. After application of $\mathrm{P}$ fertilizer to calcareous soils, a decrease in $P$ concentration level occurred within $24 \mathrm{~h}$. The adsorbed $\mathrm{P}$ might be diffused inside the $\mathrm{CaCO}_{3}$ aggregates or $\mathrm{P}$ may diffuse inside the existing cracks

Corresponding Author: J. Shamshuddin, Department of Land Management, Faculty of Agriculture, Universiti Putra Malaysia, 43400 Serdang, Malaysia 
and crevices of $\mathrm{CaCO}_{3}$ aggregates during the overnight period of incubation (Brady, 1999).

Soluble $\mathrm{P}$ compounds when added to soil react rapidly with various compounds like $\mathrm{CaCO}_{3}$ (Bertrand et al., 2003), sand (Leclerc et al., 2001), clay (Johnston et al., 1991; Toor et al., 1997), organic matter (Daly et al., 2001), iron and aluminum oxides (Toor et al., 1997) and are quickly converted to slowly available forms (Castro and Torrent, 1995). In addition to these properties, adsorption also depends on contact time between soil and $\mathrm{P}$ with temperature (Indiata et al., 1999). Adsorption from added $P$ was found at initially low levels but, slowly increased with increasing incubation period. This might be due to desorption of greater number of P ions (Agbenin and Tissen, 1995).

Surface adsorption and precipitation are the major $\mathrm{P}$ retention processes limiting the availability of applied P. However, the need for caution is stressed in interpreting correlation between $\mathrm{P}$ retention capacity (Bertrand et al., 2003) and soil properties because of the inter correlations among soil properties (Torrent, 1995). A simple correlation analysis may not be sufficient in evaluating direct influence of soil properties on $\mathrm{P}$ retention capacity (Zhang et al., 2005). Hence, this study was conducted to determine the relationship between $\mathrm{P}$ adsorption by soil at varying $\mathrm{P}$ levels and the period of incubation, which can help in $\mathrm{P}$ fertilizer recommendation and improvement of $\mathrm{P}$ fertilizer management.

\section{MATERIALS AND METHODS}

\subsection{Physico-Chemical Properties of the Soil}

The study was carried out on two soil series (Rustam and Miani) and soil samples were air-dried, crushed and passed through a $2 \mathrm{~mm}$ sieve. The soil samples were analyzed for their physico-chemical properties. Soil texture was analysed by Bouyoucos' hydrometer method, organic matter by Black and Walkley method (Jackson, 1958), lime content by Acid neutralization Purie's method (Kanwar and Chopra, 1967) and electrical conductivity by electrical conductivity meter (1:5 soil water extract). Soil $\mathrm{pH}$ was measured (water 1:5 extract) using PHM210 Standard $\mathrm{pH}$ meter at $30^{\circ} \mathrm{C}$ (Jones, 2001) and available phosphorus by AB-DTPA method (Soultanpur and Schwab, 1977).

\subsection{Phosphate Adsorption}

Phosphate adsorption data were obtained by shaking $10 \mathrm{~g}$ soil samples with $100 \mathrm{~mL}$ of $0.01 \mathrm{M} \mathrm{CaCl}_{2}$ in 300 $\mathrm{mL}$ glass bottles. The samples were prepared in triplicates. Varying $\mathrm{P}$ amounts of $0,2.5,5,10,25,50$,
100, 250, 500 and $1000 \mu \mathrm{g} \mathrm{g}^{-1}$ soil were added as $\mathrm{KH}_{2} \mathrm{PO}_{4}$ and 5 to 8 drops of toluene $\left(\mathrm{C}_{6} \mathrm{H}_{5} \mathrm{CH}_{3}\right)$ were also added to each bottle to stop microbial activity. The samples were incubated for 1, 2, 3, 7, 15, 30 and 60 days at the constant temperature of 25 and $35 \pm 1^{\circ} \mathrm{C}$ on an orbital shaker at the speed of $150 \mathrm{rpm}$. The suspensions were then filtered through Whatman filter paper No.42. Finally, the $\mathrm{P}$ was determined followed by the Murphy and Riley (1962) method. The amount of $P$ adsorbed was calculated following Fox and Kamprath (1970).

The experiment was conducted in in vitro condition following completely randomized design with three replications for 60 days of incubation period.

\subsection{Statistical Analysis}

The data so obtained were statistically analyzed using the SAS Software Program (Version 9.2) and the treatment means were separated using Tukey's test $(\mathrm{p}<0.05)$.

\section{RESULTS}

\subsection{Physico-Chemical Properties of the Soil}

Analytical data on the physico-chemical properties of the soil are presented in Table 1. Results showed both of the soil series (Rustam and Maiani) were clay loam in texture, with slight salinity ( $\mathrm{pH} 7.5$ to 7.92$)$. The electrical conductivity was low $\left(<4 \mathrm{dSm}^{-1}\right)$ and the soils were calcareous in nature $(>14 \%$ carbonate). The organic matter was low, ranging from 0.77 to $0.98 \%$ and the ABDTPA extractable phosphorus was deficient $(0.17$ to 0.2 $\mu \mathrm{g} \mathrm{g}^{-1}$ ) (Table 1).

\subsection{Phosphate Sorption in Rustum Series}

Figure 1a shows the effect of phosphorus levels and incubation period on phosphate sorption in Rustum soil series at $35 \pm 1{ }^{\circ} \mathrm{C}$. The effect of phosphorus levels and incubation period on phosphate sorption at $25 \pm 1 \div \mathrm{C}$. P sorption was increased with increasing incubation period (). During the initial 2 days of incubation period, most of the added $\mathrm{P}$ was adsorbed (40-84\%). Then adsorption of $\mathrm{P}$ decreased slowly until 60 days of incubation (Table 2). The highest $\mathrm{P}$ sorption (83.2\%) was observed for the 25 $\mu \mathrm{g} \mathrm{g}^{-1}$ treatment, but after 60 days of the incubation the highest P sorption (95.8\%) was observed when $500 \mu \mathrm{g}$ $\mathrm{g}^{-1}$ of $\mathrm{P}$ was applied. This was statistically similar from 25 to $100 \mu \mathrm{g} \mathrm{g}^{-1}$ of added P. In general the majority of the $P$ sorbed occurred at the higher amounts of the added P.

Figure 1b shows the Rustum soil, the P sorption was faster at the temperature of $35^{\circ} \mathrm{C}$ compared to that at $25^{\circ} \mathrm{C}$. 
Table 1. Physico-chemical properties of soils

\begin{tabular}{lll}
\hline Parameters & Rustam series & Miani series \\
\hline Sand (\%) & 1.0 & 6.5 \\
Silt $(\%)$ & 46.5 & 46.0 \\
Clay $(\%)$ & 52.5 & 48.5 \\
Textural Class & Clay loam & Clay loam \\
Soil reaction $(\mathrm{pH})$ & $7.95\left(\mathrm{H}_{2} \mathrm{O}\right), 7.5\left(\mathrm{CaCl}_{2}\right)$ & $7.80\left(\mathrm{H}_{2} \mathrm{O}\right), 7.61\left(\mathrm{CaCl}_{2}\right)$ \\
Electrical Conductivity $\left(\mathrm{dS} \mathrm{m}^{-1}\right)$ & $0.28\left(\mathrm{H}_{2} \mathrm{O}\right), 1.86\left(\mathrm{CaCl}_{2}\right)$ & $0.28\left(\mathrm{H}_{2} \mathrm{O}\right), 1.86\left(\mathrm{CaCl}_{2}\right)$ \\
Lime content $(\%)$ & 14.2 & 14.3 \\
Organic matter $(\%)$ & 0.98 & 0.77 \\
AB-DTPA P $\left(\mu \mathrm{g} \mathrm{g}^{-1}\right)$ & 0.17 & 0.2 \\
\hline
\end{tabular}

AB-DTPA = Ammonium Bicarbonate-DTPA

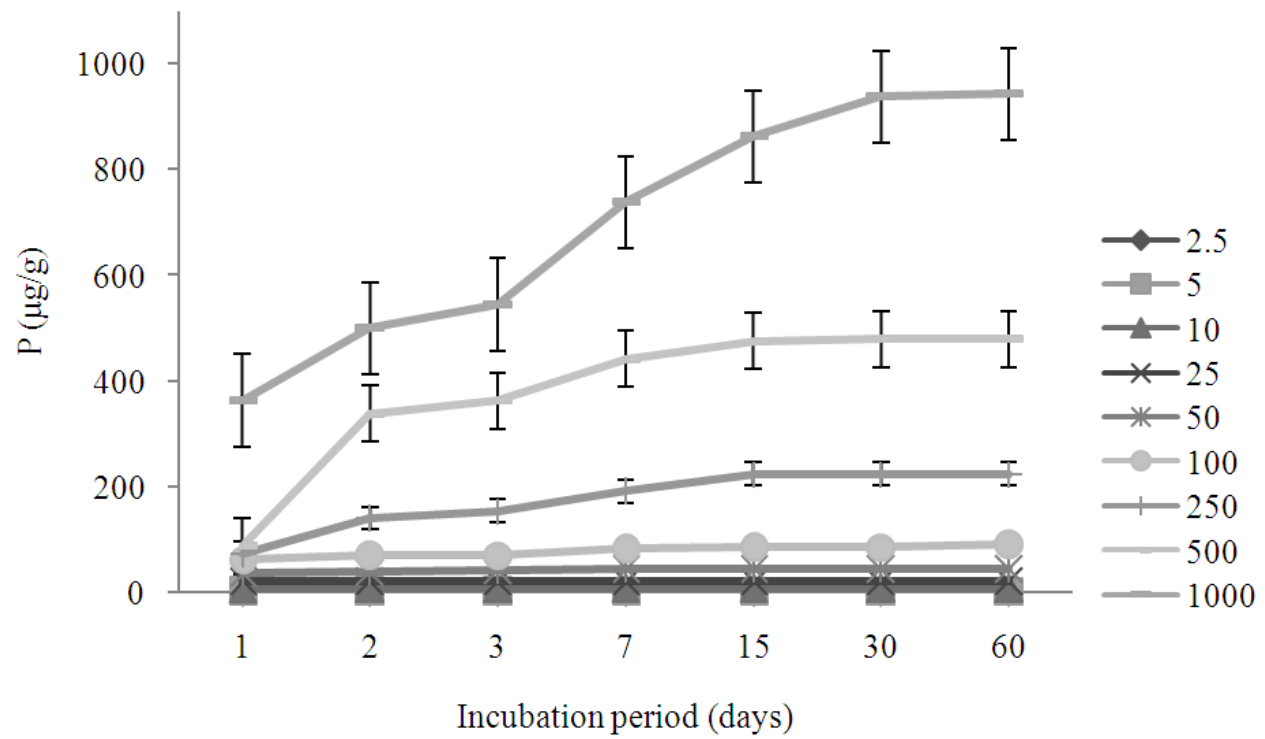

(a)

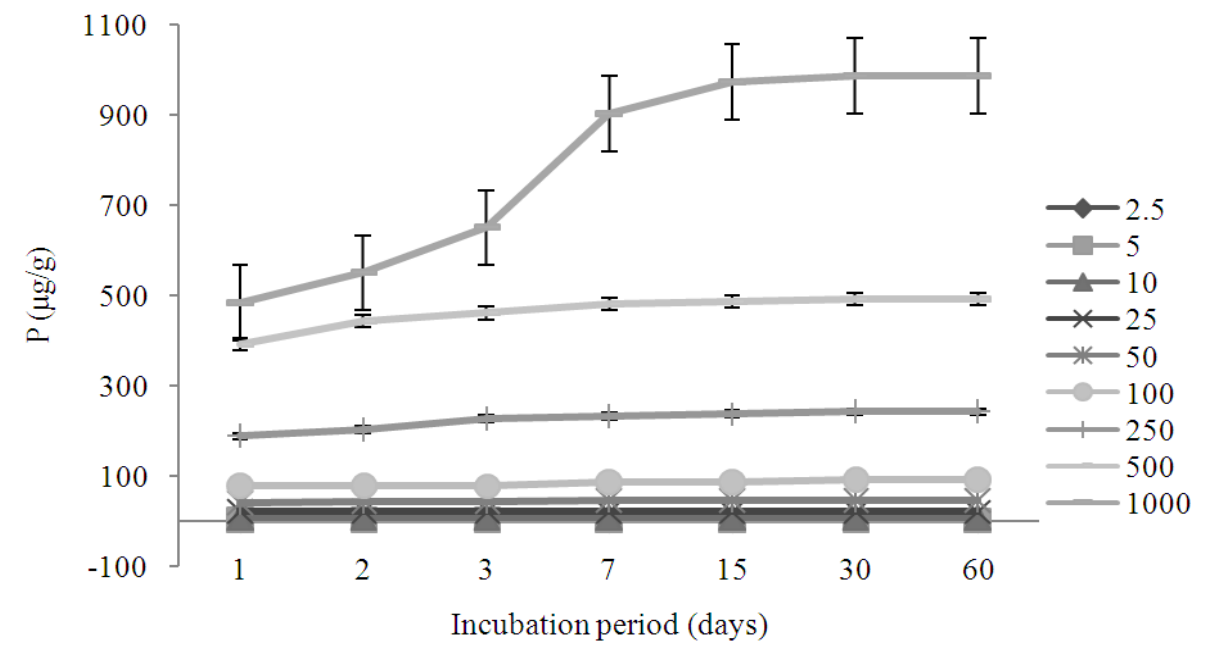

(b)

Fig. 1. Effect of phosphorus levels and incubation period on phosphate sorption in Rustum soil (a) at $25^{\circ} \mathrm{C}$ temperature (b) $35^{\circ} \mathrm{C}$ temperature 
Table 2. Effect of phosphorus levels and incubation period on phosphate sorption in Rustum soil at $25 \pm 1^{\circ} \mathrm{C}$

\begin{tabular}{|c|c|c|c|c|c|c|c|}
\hline \multirow[b]{2}{*}{$\mathrm{PA}\left(\mu \mathrm{g} \mathrm{g}^{-1}\right)$} & \multicolumn{7}{|c|}{$\begin{array}{l}\text { P sorption }(\%) \text { in Rustam soil at } 25^{\circ} \mathrm{C} \\
\text { Days }\end{array}$} \\
\hline & 1 & 2 & 3 & 7 & 15 & 30 & 60 \\
\hline 2.5 & $28.0 \mathrm{e}$ & $40.0 \mathrm{~d}$ & $40.0 \mathrm{e}$ & $40.0 \mathrm{c}$ & $44.0 \mathrm{~d}$ & $44.00 \mathrm{~d}$ & $44.0 \mathrm{~d}$ \\
\hline 5 & $40.0 \mathrm{~d}$ & $56.0 \mathrm{c}$ & $52.0 \mathrm{~d}$ & $72.0 \mathrm{~b}$ & $72.0 \mathrm{c}$ & $72.00 \mathrm{c}$ & $72.0 \mathrm{c}$ \\
\hline 10 & $60.0 \mathrm{c}$ & $74.0 \mathrm{~b}$ & 76.0ab & $79.0 \mathrm{ab}$ & $79.0 \mathrm{~b}$ & $79.00 \mathrm{~b}$ & $80.0 \mathrm{~b}$ \\
\hline 25 & $83.2 \mathrm{a}$ & $84.0 \mathrm{a}$ & $86.8 \mathrm{a}$ & $88.8 \mathrm{a}$ & $88.8 \mathrm{a}$ & $88.8 \mathrm{ab}$ & $88.8 \mathrm{a}$ \\
\hline 50 & $75.0 \mathrm{~b}$ & $80.0 \mathrm{a}$ & $83.2 \mathrm{a}$ & $88.0 \mathrm{a}$ & $88.0 \mathrm{a}$ & $88.0 \mathrm{ab}$ & $92.0 \mathrm{a}$ \\
\hline 100 & $63.7 \mathrm{c}$ & $70.0 \mathrm{~b}$ & $78.1 \mathrm{a}$ & $82.3 \mathrm{a}$ & $86.0 \mathrm{ab}$ & $86.30 \mathrm{~b}$ & $90.0 \mathrm{a}$ \\
\hline 250 & 29.6 & $56.0 \mathrm{c}$ & $61.6 c$ & $76.6 \mathrm{~b}$ & $89.6 a$ & $89.60 \mathrm{a}$ & $89.6 \mathrm{a}$ \\
\hline 500 & $17.6 \mathrm{f}$ & $67.6 \mathrm{~b}$ & $72.4 \mathrm{~b}$ & $88.4 \mathrm{a}$ & $95.0 \mathrm{a}$ & $95.80 \mathrm{a}$ & $95.8 \mathrm{a}$ \\
\hline 1000 & $36.3 \mathrm{e}$ & $50.0 \mathrm{~d}$ & $54.5 \mathrm{~d}$ & $73.8 \mathrm{~b}$ & $86.3 \mathrm{ab}$ & $93.80 \mathrm{a}$ & $94.3 \mathrm{a}$ \\
\hline
\end{tabular}

Means within the same column followed by the same letters are not significantly different at $\mathrm{p}<0.05$

$\mathrm{PA}=$ Phosphorus Added $=\mu \mathrm{g} \mathrm{g}^{-1}, \mathrm{PE}=$ Phosphorus at Equilibrium $=\mu \mathrm{g} 10 \mathrm{~mL}^{-1}, \mathrm{PS}=$ Phosphate Stored by Soil $=\mu \mathrm{g} \mathrm{g}^{-1}$

Table 3. Effect of phosphorus levels and incubation period on phosphate sorption in Rustum soil at $35 \pm 1^{\circ} \mathrm{C}$

\begin{tabular}{|c|c|c|c|c|c|c|c|}
\hline \multirow[b]{2}{*}{$\mathrm{PA}\left(\mu \mathrm{g} \mathrm{g}^{-1}\right)$} & \multicolumn{7}{|c|}{$\begin{array}{l}\text { P sorption (\%) in Rustum soil } 35^{\circ} \mathrm{C} \\
\text { Days }\end{array}$} \\
\hline & 1 & 2 & 3 & 7 & 15 & 30 & 60 \\
\hline 2.5 & $72.0 \mathrm{~b}$ & $72.0 \mathrm{~b}$ & $80.0 \mathrm{ab}$ & $80.0 \mathrm{~b}$ & $80.0 \mathrm{~b}$ & $80.0 \mathrm{~b}$ & $80.0 \mathrm{~b}$ \\
\hline 5 & $62.0 \mathrm{c}$ & $62.0 \mathrm{c}$ & $62.0 \mathrm{c}$ & $76.0 \mathrm{~b}$ & $76.0 \mathrm{~b}$ & $76.0 \mathrm{~b}$ & $76.0 \mathrm{~b}$ \\
\hline 10 & $72.0 \mathrm{~b}$ & $75.0 \mathrm{~b}$ & $75.0 \mathrm{~b}$ & $80.0 \mathrm{~b}$ & $80.0 \mathrm{~b}$ & $80.0 \mathrm{~b}$ & $80.0 \mathrm{~b}$ \\
\hline 25 & $82.4 \mathrm{a}$ & $84.4 \mathrm{a}$ & $86.4 \mathrm{a}$ & $90.0 \mathrm{a}$ & $90.0 \mathrm{a}$ & $90.0 \mathrm{a}$ & $90.0 \mathrm{a}$ \\
\hline 50 & $79.4 a$ & $86.4 \mathrm{a}$ & $87.2 \mathrm{a}$ & $92.2 \mathrm{a}$ & $92.2 \mathrm{a}$ & $92.2 \mathrm{a}$ & $92.2 \mathrm{a}$ \\
\hline 100 & $77.5 \mathrm{a}$ & $78.5 \mathrm{~b}$ & $79.6 \mathrm{~b}$ & $85.7 \mathrm{a}$ & 86.0ab & $91.0 \mathrm{a}$ & $91.0 \mathrm{a}$ \\
\hline 250 & $75.2 \mathrm{ab}$ & $81.2 \mathrm{ab}$ & $90.4 \mathrm{a}$ & $92.8 \mathrm{a}$ & $95.6 \mathrm{a}$ & $96.8 \mathrm{a}$ & $96.8 \mathrm{a}$ \\
\hline 500 & $78.2 \mathrm{a}$ & $88.6 a$ & $92.2 \mathrm{a}$ & $96.2 \mathrm{a}$ & $97.2 \mathrm{a}$ & $98.2 \mathrm{a}$ & $98.2 a$ \\
\hline 1000 & $48.5 \mathrm{~d}$ & $55.0 \mathrm{~d}$ & $65.0 \mathrm{c}$ & $90.3 \mathrm{a}$ & $97.3 \mathrm{a}$ & $98.7 \mathrm{a}$ & $98.7 \mathrm{a}$ \\
\hline
\end{tabular}

Means within the same column followed by the same letters are not significantly different at $\mathrm{p}<0.05 \mathrm{PA}=$ phosphorus added $=\mu \mathrm{g}$ $\mathrm{g}^{-1}, \mathrm{PE}=$ phosphorus at equilibrium $=\mu \mathrm{g} 10 \mathrm{~mL}^{-1}, \mathrm{PS}=$ phosphate stored by soil $=\mu \mathrm{g} \mathrm{g}^{-1}$

About more than half of the $\mathrm{P}$ was adsorbed (48.5$82.4 \%$ ) after 1 day of incubation period for all treatments (Table 3). The highest $\mathrm{P}$ sorption was recorded $(82.4 \%)$ for the $25 \mu \mathrm{g} \mathrm{g}^{-1}$ treatment, which was statistically similar to $500 \mu \mathrm{g} \mathrm{g}^{-1}$ treatment. However, after 60 days of incubation the highest $\mathrm{P}$ sorption (98.7\%) was observed for the $1000 \mu \mathrm{g} \mathrm{g}^{-1}$ treatment and this was statistically similar to the 25 to $1000 \mu \mathrm{g} \mathrm{g}^{-1}$ treatments. The amount of the $\mathrm{P}$ sorption was higher at the temperature of $35^{\circ} \mathrm{C}$ compared to that at the lower temperature. It shows that $\mathrm{P}$ adsorption is significantly affected by the temperature. The rate of $\mathrm{P}$ adsorption decreased after 7 days of the incubation, but it increased after 60 days where most of the added $\mathrm{P}$ was adsorbed (60-98.7\%).

\subsection{Phosphate Sorption in Miani Series}

Figure 2a shows Effect of phosphorus levels and incubation period on phosphate sorption in Miani soil at $25 \pm 1^{\circ} \mathrm{C}$. The Miani soil almost gave the same trend of the $\mathrm{P}$ sorption at both temperatures. The soil $\mathrm{P}$ sorption increased with the incubation period. The highest $\mathrm{P}$ sorption $(79.2 \%)$ was observed in 25 and $50 \mu \mathrm{g} \mathrm{g}^{-1}$ treatments, but after 60 days of incubation the highest $\mathrm{P}$ sorption (96.6\%) was observed in $500 \mu \mathrm{g} \mathrm{g}^{-1}$ treatment and this was statistically similar to that of 10 to $1000 \mu \mathrm{g}$ $\mathrm{g}^{-1}$ treatments. During the first 3 days of incubation period, most of the added $\mathrm{P}$ was adsorbed (28-85.2\%) then the rate of adsorption decreased after 60 days of incubation (Table 4). At 60 days of incubation period, $\mathrm{P}$ sorbed was $32-96.6 \%$. It shows that most the added $\mathrm{P}$ was adsorbed slowly and significantly increased at the higher rates of $\mathrm{P}$ addition.

Figure 2b shows like Rustum soil, $\mathrm{P}$ sorption in Miani soil was faster at $35^{\circ} \mathrm{C}$ compared to that at $25^{\circ} \mathrm{C}$ during the incubation period. Almost more than half of the added $\mathrm{P}$ was adsorbed (29.9-82\%) after 1 day of the incubation at all levels of $P$ (Table 5). At 60 days of the incubation, the highest $\mathrm{P}$ sorption (98.6\%) was observed in $1000 \mu \mathrm{g} \mathrm{g} \mathrm{g}^{-1}$ treatment, which was statistically similar to that of $25 \mu \mathrm{g} \mathrm{g}^{-1}$ treatment. The 
rate of $\mathrm{P}$ sorption was higher at $25^{\circ} \mathrm{C}$ compared to that at higher temperature. It shows that temperature affected the $\mathrm{P}$ sorption in the soil. After 3days of incubation, the amount of the $\mathrm{P}$ adsorbed decreased.

\subsection{Phospahte Equilibrium in Rustam Series}

Figure 3a shows the effect of phosphorus levels and incubation period on phosphate equilibrium in Rustum soil at $25 \pm 1^{\circ} \mathrm{C}$. The $\mathrm{P}$ levels affected the equilibrium of $\mathrm{P}$ in Rustum soil with its equilibrium decreased with the incubation period. During the first three 3 days of incubation, it was rapidly reduced then the reduction slowed down except for the $\mathrm{P}$ level of $1000 \mu \mathrm{g} \mathrm{g}^{-1}$, followed by $500 \mu \mathrm{g} \mathrm{g}^{-1}$ ).

Figure 3b shows the effect of phosphorus levels and incubation period on phosphate equilibrium in Rustum soil at $35 \pm 1^{\circ} \mathrm{C}$. At higher temperature, the $\mathrm{P}$ equilibrium showed the same trend like at $25 \pm 1^{\circ} \mathrm{C}$.

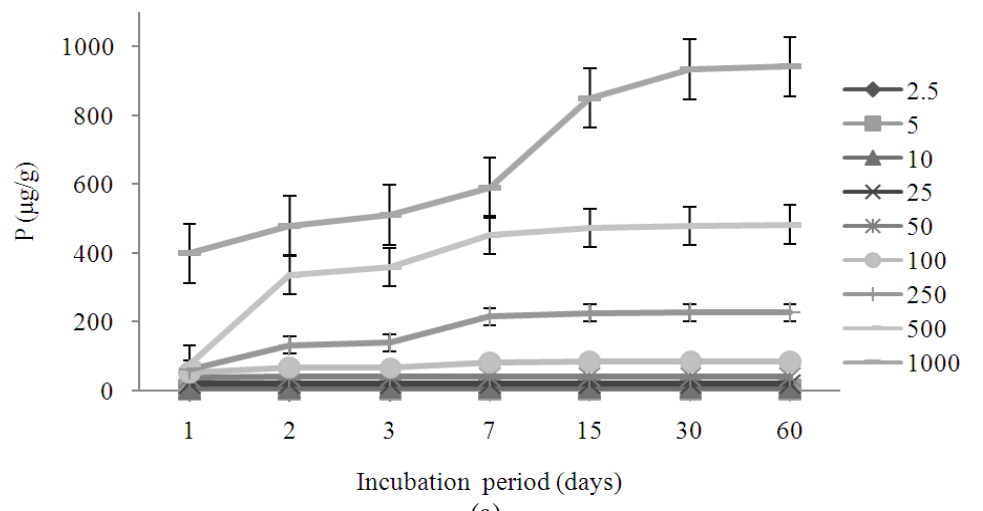

(a)

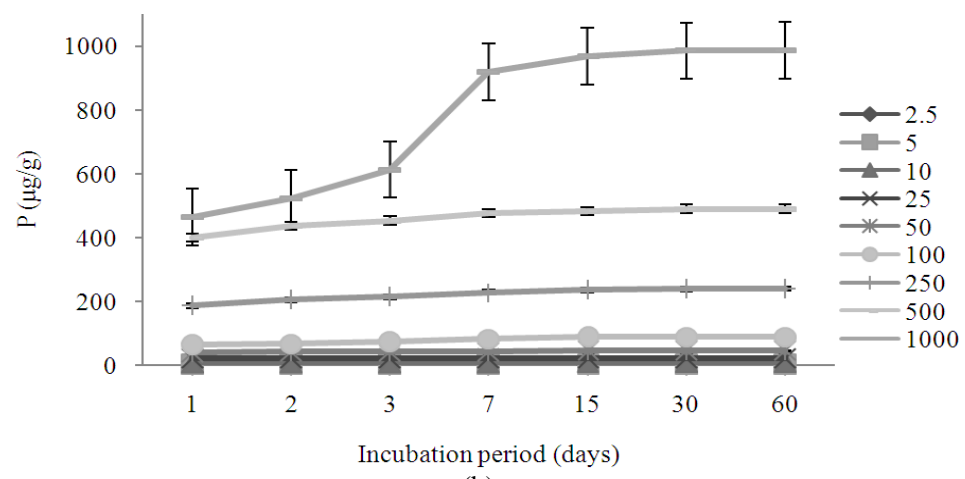

(b)

Fig. 2. Effect of phosphorus levels and incubation period on phosphate sorption in Miani soil (a) at $25^{\circ} \mathrm{C}$ temperature (b) $35^{\circ} \mathrm{C}$ temperature

Table 4. Effect of phosphorus levels and incubation period on phosphate sorption in Miani soil at $25 \pm 1^{\circ} \mathrm{C}$

\begin{tabular}{|c|c|c|c|c|c|c|c|}
\hline \multirow[b]{2}{*}{$\mathrm{PA}\left(\mu \mathrm{g} \mathrm{g}^{-1}\right)$} & \multicolumn{7}{|c|}{$\begin{array}{l}\text { P sorption (\%) in Miani soil at } 25^{\circ} \mathrm{C} \\
\text { Days }\end{array}$} \\
\hline & 1 & 2 & 3 & 7 & 15 & 30 & 60 \\
\hline 2.5 & 20de & $28 \mathrm{~d}$ & $28 \mathrm{e}$ & $32 \mathrm{~d}$ & $32 \mathrm{~d}$ & $32 \mathrm{~d}$ & $32 \mathrm{~d}$ \\
\hline 5 & $56 \mathrm{~b}$ & $62 \mathrm{~b}$ & $64 c$ & $66 c$ & $66 c$ & $66 c$ & $66 \mathrm{c}$ \\
\hline 10 & $62 \mathrm{~b}$ & $75 \mathrm{a}$ & $77 \mathrm{ab}$ & $81 b$ & $83 b$ & $83 \mathrm{~b}$ & $83 b$ \\
\hline 25 & $79.2 \mathrm{a}$ & $84.8 \mathrm{a}$ & $85.2 \mathrm{a}$ & $85.2 \mathrm{a}$ & $85.2 \mathrm{ab}$ & $85.2 \mathrm{ab}$ & $85.2 \mathrm{ab}$ \\
\hline 50 & $75.6 \mathrm{a}$ & $83 a$ & $84 a$ & $84.6 \mathrm{a}$ & $84.6 \mathrm{ab}$ & $84.6 \mathrm{ab}$ & $84.6 \mathrm{ab}$ \\
\hline 100 & $53.1 \mathrm{c}$ & $66.1 \mathrm{~b}$ & $68.4 \mathrm{~b}$ & $81.3 b$ & $84 \mathrm{ab}$ & $84 a b$ & $84 \mathrm{ab}$ \\
\hline 250 & $24.8 \mathrm{~d}$ & $53.2 \mathrm{c}$ & $55.6 \mathrm{~d}$ & $86 a$ & $90.4 \mathrm{a}$ & $90.8 \mathrm{a}$ & $90.8 \mathrm{a}$ \\
\hline 500 & $15.2 \mathrm{e}$ & $67.2 \mathrm{~b}$ & $72 b$ & $90.6 \mathrm{a}$ & $94.8 \mathrm{a}$ & $96 a$ & $96.6 \mathrm{a}$ \\
\hline 1000 & $32 \mathrm{~d}$ & $48 c$ & $51 d$ & $59 \mathrm{c}$ & $85 \mathrm{ab}$ & $93.3 \mathrm{a}$ & $94.1 \mathrm{a}$ \\
\hline
\end{tabular}

Means within the same column followed by the same letters are not significantly different at $\mathrm{p}<0.05$

$\mathrm{PA}=$ Phosphorus Added $=\mu \mathrm{g} \mathrm{g}^{-1}, \mathrm{PE}=$ Phosphorus at Equilibrium $=\mu \mathrm{g} 10 \mathrm{~mL}^{-1}, \mathrm{PS}=$ Phosphate Stored by Soil $=\mu \mathrm{g} \mathrm{g}{ }^{-1}$ 
Rajput, A. et al. / American Journal of Agricultural and Biological Sciences 9 (2): 251-260, 2014

Table 5. Effect of phosphorus levels and incubation period on phosphate sorption in Miani soil at $35 \pm 1{ }^{\circ} \mathrm{C}$

\begin{tabular}{|c|c|c|c|c|c|c|c|}
\hline \multirow[b]{2}{*}{$\mathrm{PA}\left(\mu \mathrm{g} \mathrm{g}^{-1}\right)$} & \multicolumn{7}{|c|}{$\begin{array}{l}\mathrm{P} \text { sorption }(\%) \text { in Miani soil at } 35^{\circ} \mathrm{C} \\
\text { Days }\end{array}$} \\
\hline & 1 & 2 & 3 & 7 & 15 & 30 & 60 \\
\hline 2.5 & $40 \mathrm{~d}$ & $40 \mathrm{c}$ & $48 \mathrm{~d}$ & $48 \mathrm{~d}$ & $48 \mathrm{~d}$ & $48 \mathrm{~d}$ & $48 \mathrm{~d}$ \\
\hline 5 & $56 c$ & $56 \mathrm{~b}$ & $64 c$ & $66 c$ & $66 c$ & $66 c$ & $66 c$ \\
\hline 10 & $74 \mathrm{~b}$ & $80 \mathrm{a}$ & $80 \mathrm{~b}$ & $80 \mathrm{~b}$ & $82 \mathrm{~b}$ & $82 b$ & $83 b$ \\
\hline 25 & $82 \mathrm{a}$ & $85.2 \mathrm{a}$ & $85.6 \mathrm{a}$ & $85.6 \mathrm{a}$ & $85.6 \mathrm{a}$ & $85.6 \mathrm{a}$ & $85.6 \mathrm{a}$ \\
\hline 50 & $77.8 \mathrm{a}$ & $87.8 \mathrm{a}$ & $88 \mathrm{a}$ & $89.8 \mathrm{a}$ & $89.8 \mathrm{a}$ & $90 \mathrm{a}$ & $90 \mathrm{a}$ \\
\hline 100 & $64 c$ & 68.9 & $73.8 \mathrm{~b}$ & $84.5 \mathrm{a}$ & $88.3 \mathrm{a}$ & $90 \mathrm{a}$ & $90 \mathrm{a}$ \\
\hline 250 & 29.9 & $82.6 \mathrm{a}$ & $85.6 \mathrm{a}$ & $91.6 \mathrm{a}$ & $94.4 \mathrm{a}$ & $95.6 \mathrm{a}$ & $95.6 \mathrm{a}$ \\
\hline 500 & $79.8 \mathrm{a}$ & $87.4 \mathrm{a}$ & $90.6 \mathrm{a}$ & $95.4 \mathrm{a}$ & $96.4 \mathrm{a}$ & $98 \mathrm{a}$ & $98 \mathrm{a}$ \\
\hline 1000 & $46.5 \mathrm{~d}$ & $52.4 \mathrm{~b}$ & $61.3 \mathrm{c}$ & $91.2 \mathrm{a}$ & $96.7 \mathrm{a}$ & $98.5 \mathrm{a}$ & $98.6 \mathrm{a}$ \\
\hline
\end{tabular}

Means within the same column followed by the same letters are not significantly different at $p<0.05$

$\mathrm{PA}=$ Phosphorus Added $=\mu \mathrm{g} \mathrm{g}^{-1}, \mathrm{PE}=$ Phosphorus at Equilibrium $=\mu \mathrm{g} 10 \mathrm{~mL}^{-1}, \mathrm{PS}=$ Phosphate Stored by Soil $=\mu \mathrm{g} \mathrm{g}{ }^{-1}$

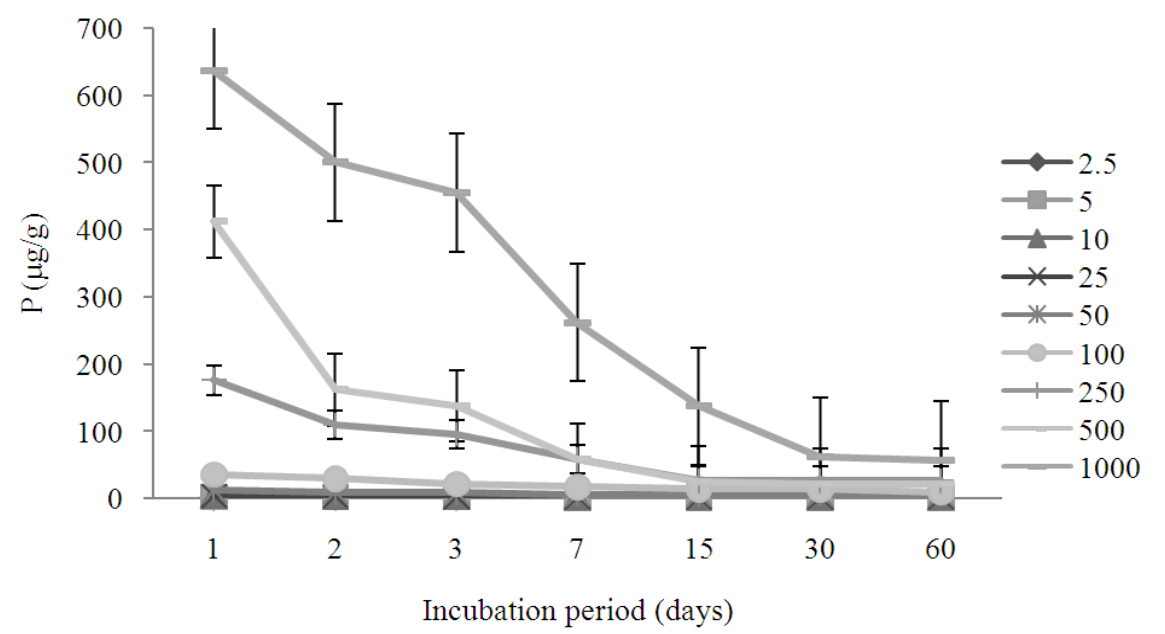

(a)

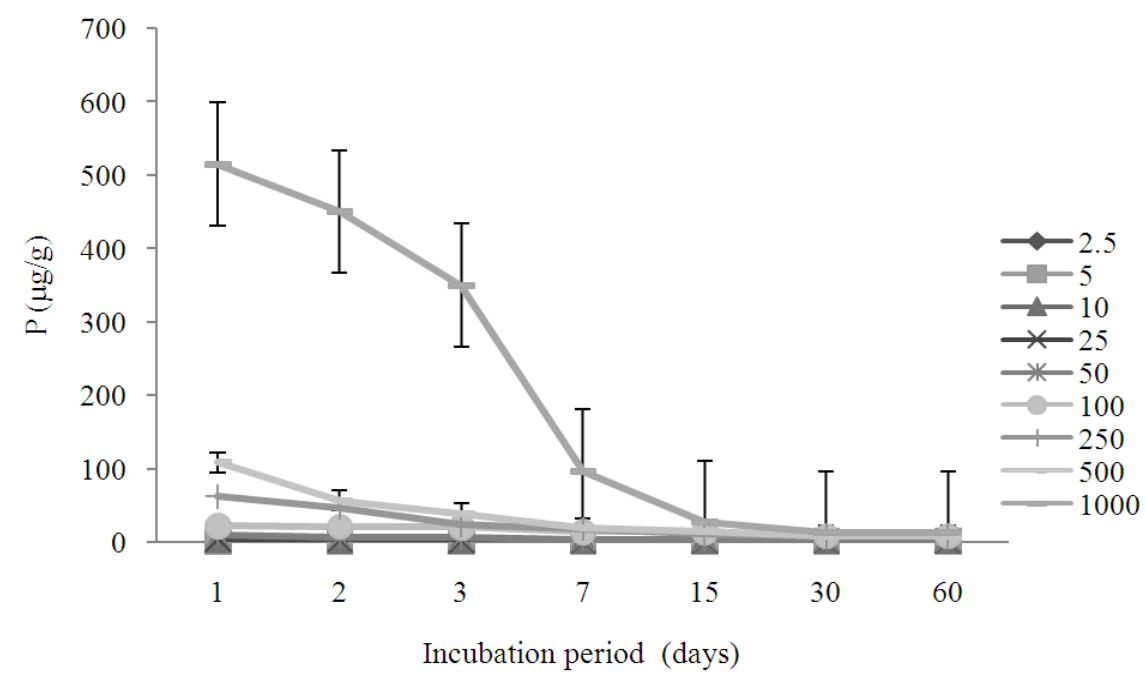

(b)

Fig. 3. Effect of $\mathrm{P}$ levels and incubation period on $\mathrm{P}$ equilibrium in Rustun soil (a) at $25^{\circ} \mathrm{C}$ temperature (b) $35^{\circ} \mathrm{C}$ temperature 


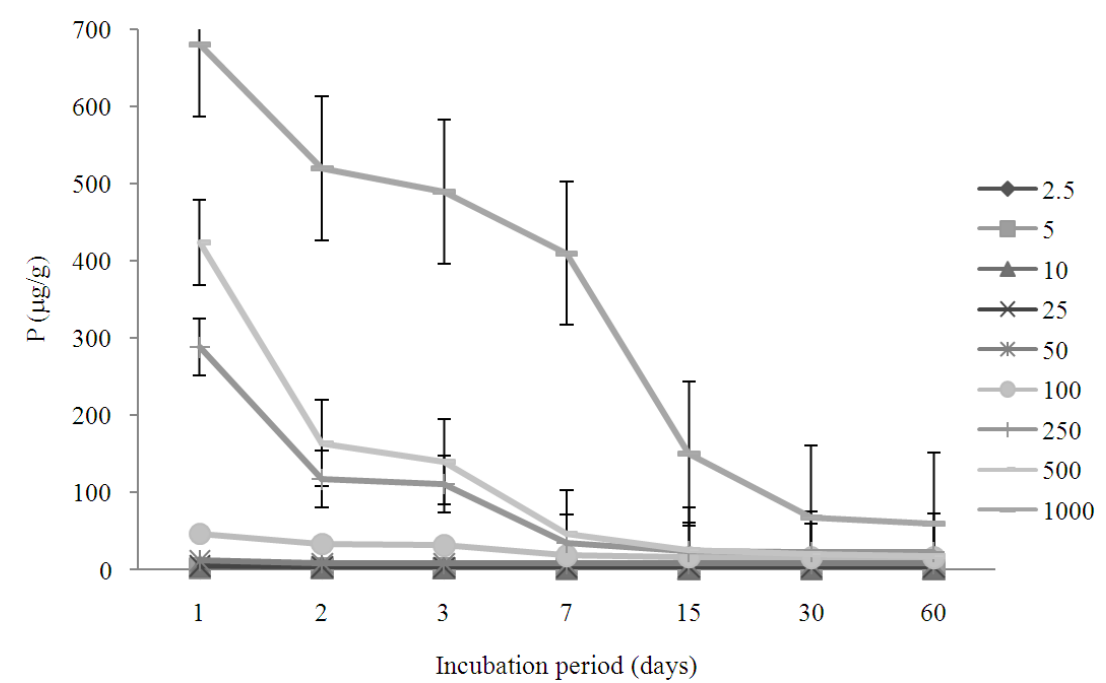

(a)

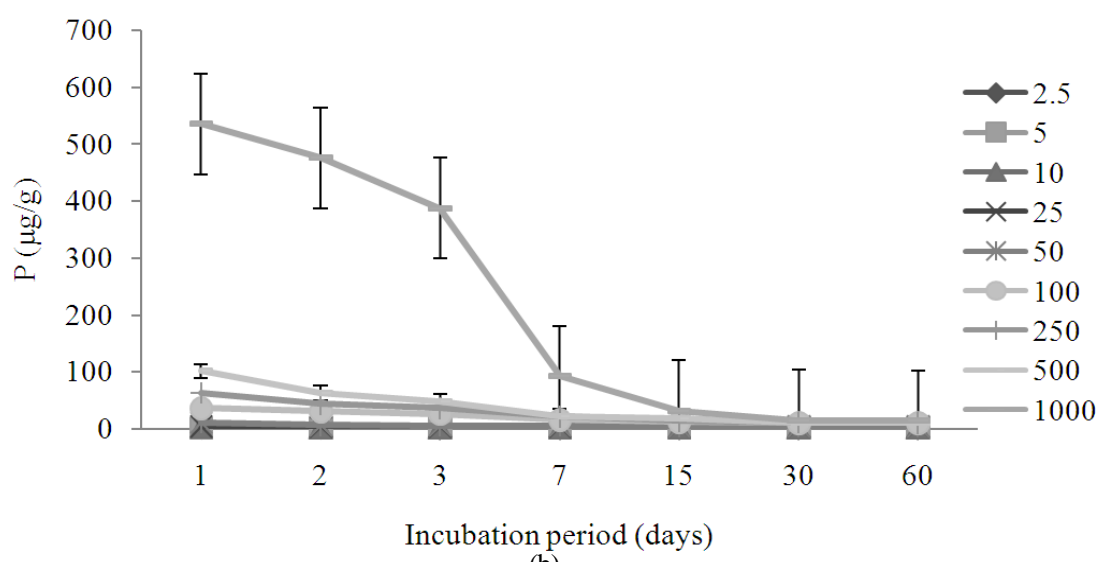

(b)

Fig. 4. Effect of incubation on $\mathrm{P}$ equilibrium in miani soil: (a) at $25^{\circ} \mathrm{C}$ temperature (b) at $35^{\circ} \mathrm{C}$ temperature

During the first 2 days of incubation, all $\mathrm{P}$ equilibrium levels were low, except for $1000 \mu \mathrm{g} \mathrm{g}^{-1}$ treatment. After 3 to 7 days, almost more than half of the equilibrium levels of $\mathrm{P}$ were reduced. Whereas, at the highest $\mathrm{P}$ level $\left(1000 \mu \mathrm{g} \mathrm{g}^{-1}\right)$, it was observed that $\mathrm{P}$ equilibrium in the soil was not achieved even after 60 days of incubation, but it was higher at $35^{\circ} \mathrm{C}$ than it was at $25^{\circ} \mathrm{C}$.

\subsection{Phospahte Equilibrium in Miani Series}

The effect of phosphorus levels and incubation period on phosphate equilibrium in Miani soil at $25 \pm 1{ }^{\circ} \mathrm{C}$. $\mathrm{P}$ levels affected the equilibrium of $\mathrm{P}$ in Miani soil during the incubation period. The trend of reduction was similar to that of Rustum soil. The $\mathrm{P}$ equilibrium decreased with the incubation period. It was rapidly reduced in the first week of incubation then the reduction was slowed down except for the lower $\mathrm{P}$ levels $\left(2.5,10,25,50\right.$ and $\left.100 \mu \mathrm{g} \mathrm{g}^{-1}\right)$ (Fig. 4a).

Figure 4b shows the effect of phosphorus levels and incubation period on phosphate equilibrium in Miani soil at $35 \pm 1^{\circ} \mathrm{C}$. The equilibrium of $\mathrm{P}$ was reduced quickly at all levels, except for the $1000 \mu \mathrm{g} \mathrm{g}^{-1}$ treatment $\left({ }^{\circ} \mathrm{C}\right)$. In general, after 15 days of incubation, all levels of $\mathrm{P}$ equilibrium had reduced to lower levels. For both temperatures, there was similar reduction found in $\mathrm{P}$ equilibrium during the incubation period. Furthermore, at the highest $\mathrm{P}$ level $(1000 \mu \mathrm{g}$ $\left.\mathrm{g}^{-1}\right)$, it was observed that in soil the equilibrium was not achieved even at 60 days of incubation, but it was different from that at the $25^{\circ} \mathrm{C}$. 


\section{DISCUSSION}

Rustum and Miani soils were similar in their properties, except there slightly higher clay content in Miani soil. It is known that clayey soils with high $\mathrm{pH}$ have more $\mathrm{P}$ problems due to the bondage of $\mathrm{P}$ with other cations such as $\mathrm{Ca}$ and $\mathrm{Na}$. Result of the current study showed that soil with high clay content adsorbed more applied P. Likewise, soil with $\mathrm{CaCO}_{3}$ adsorbed more applied P. However, reverse trend was true for the available $\mathrm{P}$ and organic matter contents. Soils with more available $\mathrm{P}$ as well as high organic matter retained less applied $\mathrm{P}$.

Both of the soils showed similar trend of $\mathrm{P}$ sorption during the incubation period. However, a slight increase in $\mathrm{P}$ sorption was observed in Miani soil at 60 days of incubation. The P sorption increased with the incubation period. Most of the $\mathrm{P}$ was sorbed within one week and the remaining portion was slowly adsorbed thereafter (Cyr et al., 2009). The slow reaction between $\mathrm{P}$ in the solution and soil particles continued up to the incubation time, one distinct behavior of $\mathrm{P}$ in the soil. The rates of $\mathrm{P}$ sorption by the both soils were initially fast and then slowed down for a long time without any evidence of ending. This finding is in agreement with that of Huang et al. (2012). It might be due to the initial sorption of greater number of $\mathrm{P}$ ions. Comparatively higher amounts of $\mathrm{P}$ sorption occurred with the high amounts of $\mathrm{P}$ added to the soil and maximum amounts of the $\mathrm{P}$ sorbed in all the added $\mathrm{P}$ at the end of incubation period. Singh et al. (1990) found similar trend of P sorption.

The release of the $\mathrm{P}$ in the soils depends on the soil characteristics, especially soil texture. The increased $\mathrm{P}$ release occurred due to less clay content and more native $\mathrm{P}$ along with the increasing initial phosphorus level. Soil $\mathrm{P}$ can be affected by clay and $\mathrm{CaCO}_{3}$ content in the soil. The more the clay content is the more $\mathrm{P}$ is needed to be applied into the soil. Kaloi et al. (2011) reported that $\mathrm{P}$ adsorbing capacity of soils always depends on clay contents and native soil $\mathrm{P}$.

Result of this study showed that clay and $\mathrm{CaCO}_{3}$ contents severely affected the sorption of $\mathrm{P}$. The sorption of heavy textured soils can be decreased using organic matter (Kaloi et al., 2010). Similar findings were observed by Moazed et al. (2010) and Javid and Rowell (2002) that P sorption was considerably linked to clay and organic matter content of the soil. Furthermore, Rashid and Rowell (1988) reported that total P absorbed was directly connected to total surface area and soil clay contents. At low $\mathrm{P}$ concentration, total $\mathrm{P}$ adsorbed increased with increase in total surface area. The soils containing low content of clay with high native $\mathrm{P}$ required lower doses of $\mathrm{P}$ as soils have less $\mathrm{P}$ adsorbing capacity and adsorbed $\mathrm{P}$ can easily be released. In addition, soil $\mathrm{P}$ adsorption at lower concentration in equilibrium solution appears to be managed by the iron oxides while at high concentration by the Ca-P precipitation (Mehmood et al., 2010).

Temperature is a crucial factor affecting $\mathrm{P}$ sorption in soils. Temperature plays significant role in the sorption of P. Both of the soils under study had similar behavior for $\mathrm{P}$ sorption. More $\mathrm{P}$ was adsorbed at $35^{\circ} \mathrm{C}$ than it was at $25^{\circ} \mathrm{C}$. This result is consistent with the study of Sinegani and Sedri (2011). Furthermore, P significantly increased the soluble and loosely bound $\mathrm{P}$ aluminum-bound and iron-bound $\mathrm{P}$. The amount of $\mathrm{Al}-\mathrm{P}$ and $\mathrm{Fe}-\mathrm{P}$ was markedly higher at $30^{\circ} \mathrm{C}$ than that at $4{ }^{\circ} \mathrm{C}$ (Huang et al., 2011). For the soils under study, it was observed an increase in $\mathrm{P}$ sorption with temperature In addition, at high temperature a large proportion of $\mathrm{P}$ adsorbed permanently, thereby decreasing the equilibrium $\mathrm{P}$ concentration in soil solution Huang et al. (2012). In addition temperature plays a significant role for the glucose concentrations (Soares et al., 2011) and in soil due to the presence of microbial activity may also alter (Branzini et al., 2014).

Phosphate sorption was reported to increase with increasing temperature. On the other hand, rate of $\mathrm{P}$ sorption and desorption decreased when the equilibration temperature is lowered. The effect of temperature on the process was noticed during the first day of equilibration. Less $\mathrm{P}$ was observed in the equilibrating solution at the low temperature (Mamo et al., 2005). From the results of the study it was found that $\mathrm{P}$ sorption for soil series is of the following order: Miani Soil $>$ Rustum soil at 60 days of incubation period and $35^{\circ} \mathrm{C}$ temperature. Consistent reports were obtained by Dahar (2002) and Katiar (2002). According to their observation, the soil with the more clay content sorbed more applied P. However, the reverse was true for the available $\mathrm{P}$ and organic matter content. The soils with more available $\mathrm{P}$ as well as higher organic matter retain less applied P. This trend of increasing $\mathrm{P}$ sorption by the soil was demonstrated from the minimum of one day to the maximum of 60 days of incubation. These results are supported by the findings of Memon (2004). The soil has itself buffering capacity which due to the temperature could influence and may effect on the $\mathrm{P}$ sorption and other chemical compositions (Al-Dabbas et al., 2010).

For both soils, it was further observed that the equilibrium between $\mathrm{P}$ added in solution and sorbed $\mathrm{P}$ by the soil was obtained earlier at the low P level. However; 
the equilibrium of $\mathrm{P}$ in $1000 \mu \mathrm{g} \mathrm{g}^{-1}$ treatment could not be achieved before 60 days of incubation. The longer the time of incubation, the higher was the phosphate sorption. Similar result was reported by Huang et al. (2012).

\section{CONCLUSION}

The results of this study suggested that increase in applied $\mathrm{P}$ during incubation period resulted in higher $\mathrm{P}$ sorption in both soils. The temperature of incubation affected $\mathrm{P}$ sorption and that it was higher at $35^{\circ} \mathrm{C}$ than it was at $25^{\circ} \mathrm{C}$. It was found that soil with more clay content had higher $\mathrm{P}$ sorption capacity and needed higher amount of $\mathrm{P}$, while more native $\mathrm{P}$ in the soil resulted in less $\mathrm{P}$ sorption. It was observed from the study that with increase in the temperature directly influences the $\mathrm{P}$ sorption and in future might be different soil series could be studied for further aspects.

\section{ACKNOWLEDGMENT}

The researchers grateful to Universiti Putra Malaysia and Sindh Agriculture University Tandojam for providing technical and financial support.

\section{REFERENCES}

Agbenin, J.D. and Tiessen, 1995. Phosphorus sorption at field capacity and soil ionic strength kinetic and transformation. Soil Sci. Soc. Am. Proc. Aus. J. Soil Res., 41: 61-76.

Al-Dabbas, M.M., K. Al-Ismail, R.A. Taleb and S. Ibrahim, 2010. Acid-base buffering properties of five legumes and selected food in vitro. Am. J. Agric. Biol. Sci., 5: 154-160. DOI: 10.3844/ajabssp.2010.154.160

Bertrand, I., R.E. Holloway, R.D. Armstrong and M.J. McLaughlin, 2003. Chemical characteristics of phosphorus in alkaline soils from southern. Aust. J. Soil Res., 41: 61-76. DOI: 10.1071/SR02021

Brady, N.C., 1999. The Nature and Properties of Soils. 12th Edn., Prentice Hall, Co., New York, ISBN-10: 0138524440, pp: 881.

Branzini, A., M.S. Zubillaga and M.M. Zubillaga, 2014. Microbial response to the application of amendments in a contaminated soil with trace elements. Am. J. Environ. Sci., 5: 94-98. DOI: 10.3844/ajessp.2009.94.98
Bubba, K.E., E. Oxtabong and E. Barberies, 2001. Phosphorus adsorption maximum of sands for use as media in subsurface flow constructed reed beds as measured by the Langmuir isotherm. Water Res., 37: 3390-3400. DOI: $10.1016 /$ S00431354(03)00231-8

Castro, B. and J. Torrent, 1995. Phosphate availability in calcareous vertisols and inceptisols in relation to fertilizer type and soil properties. Fert. Res., 40: 109-119. DOI: 10.1007/BF00750095

Cyr, H., S.K. McCabe and G.K. Nurnberg, 2009. Phosphorus sorption experiments and the potential for internal phosphorus loading in littoral areas of a stratified lake. Water Res., 43: 1654-1666. DOI: 10.1016/j.watres.2008.12.050

Dahar, G.J., 2002. Distribution of micronutrients at various depths in different soil series around Tandojam. Unpublished Dissertation in Partial Fulfillment of the Requirements for the Degree of M.Sc. (Agri.), Sindh Agriculture University, Tandojam, Pakistan.

Daly, K., D. Jeffrey and H. Tunney, 2001. The effect of soil type on phosphorus sorption capacity and desorption dynamics in Irish grassland soils. Soil Use Manage., 17: 12-20. DOI: 10.1111/j.14752743.2001.tb00003.x

Devau, N., L.E. Cadre, P. Hinsinger and F. Gerard, 2010. A mechanistic model for understanding root-induced chemical changes controlling phosphorus availability. Ann. Bot., 105: 1183-1197. DOI: 10.1093/aob/mcq098

Fox, R.L. and E.J. Kamprath, 1970. Phosphate sorption isotherms for evaluating the phosphate requirements of soils. Soil Sci. Soc. Amer. Proc., 34: 902-907. DOI: $10.2136 /$ sssaj1970.03615995003400060025x

Huang, L., L. Fu, C. Jin, G. Gielen and X. Lin et al., 2011. Effect of temperature on phosphorus sorption to sediments from shallow eutrophic lakes. Ecol. Eng., 37: 1515-1522. DOI: 10.1016/j.ecoleng.2011.05.006

Huang, L., L. Li and L. Huang, 2012. Influence of incubation time on phosphorus sorption dynamics in lake sediments. J. Soils Sed., 12: 443-455. DOI: 10.1007/s11368-011-0455-z

Indiata, R., A. Coppla and A. Buondonno, 1999. Changes of soil phosphorus availability in Italian Alfisols as estimated by short term soil = phosphorus equilibration procedures using Olsen, Mehlich 3 and paper-Strip methods. Commun. Soil Sci. Plant Anal., 30: 983-997. DOI: 10.1080/00103629909370262 
Jackson, M.L., 1958. Soil Chemical Analysis. 1st Edn., Prentice Hall, Inc., Englewood Cliffs, NJ.

Javid, S. and D. Rowell, 2002. Effect of soil properties on phosphate adsorption in calcareous soils of Pakistan. Pak. J. Soil Sci., 21: 47-55.

Johnston, M.A., N. Miles and G.R. Thibaud, 1991. Quantities of phosphorus fertilizer required to raise the soil test value. South Afr. J. Plant Soil, 8: 17-21. DOI: $10.1080 / 02571862.1991 .10634573$

Jones, J.B. Jr., 2001. Laboratory Guide for Conducting Soil Tests and Plant Analysis. 1st Edn., CRC Press, LLC, New York, ISBN-10: 1420025295, pp: 384.

Kaloi, G.M., N. Bhughio, R.N. Panhwar, S. Junejo, A.H. Mari and M.A. Bhutto, 2011. Influence of incubation period on phosphate release in two soils of District Hyderabad. J. Anim. Plant Sci., 21: 665670.

Kaloi, G.M., R.N. Panhwar, A.H. Mari, S. Junejo and M.A. Bhutto et al., 2010. Influence of incubation period on phosphate sorption in two soils of District Hyderabad. Pakistan J. Sci., 62: 145-151.

Kanwar, J.S. and L. Chpras, 1967. Practical Agricultural Chemistry. Government Agricultural College, Ludhiana, India.

Katiar, N.K., 2002. Distribution of salts at various depths in different soil series around Tandojam. Unpublished Dissertation in Partial Fulfillment of the Requirements for the Degree of M.Sc. (Agri.), Sindh Agriculture University, Tandojam, Pakistan.

Khan, M.S., A. Zaidi and P.A. Wani, 2007. Role of phosphate solubilizing microorganisms in sustainable agriculture-A review. Agron. Sustain. Dev., 27: 29-43. DOI: 10.1051/agro:2006011

Leclerc, M.L., M.C. Nolin, D. Cluis and R.R. Simard, 2001. Grouping soils of the montreal lowlands (Quebec) according to fertility and P sorption and desorption characteristics. Can. J. Soil Sci., 81: 7183. DOI: $10.4141 / \mathrm{S} 00-021$

Mamo, M., S.C. Gupta, C.J. Rosen and U.B. Singh, 2005. Phosphorus leaching at cold temperatures as affected by wastewater application and soil phosphorus levels. J. Environ. Q., 34: 1243-1250. DOI: $10.2134 /$ jeq2004.0339

Mehmood, A., M.S. Akhtar, R. Hayat and M. Memon, 2010. Phosphorus adsorption parameters in relation to soil characteristics. J. Chemical Soc. Pakistan, 32: 131-139.

Memon, F.S., 2004. Effect of incubation and salinity levels on phosphate sorption. Unpublished Dissertation in Partial Fulfillment of the Requirements for the Degree of M.Sc. (Agri.), Sindh Agriculture University, Tandojam, Pakistan.
Moazed, H., Y. Hoseini, A.A. Naseri and F. Abbasi, 2010. Determining phosphorus adsorption isotherm in soil and its relation to soil characteristics. Int. J. Soil Sci., 5: 131-139. DOI: 10.3923/ijss.2010.131.139

Murphy, J. and J.P. Riley, 1962. A modified single solution method for the determination of phosphate in natural waters. Anal. Chem. Act., 27: 31-36. DOI: 10.1016/S0003-2670(00)88444-5

Onweremadu, E.U., 2007. Predicting phosphorus sorption characteristics in highly weathered soils of SouthEastern Nigeria. Res. J. Environ. Sci., 1: 47-55. DOI: 10.3923/rjes.2007.47.55

Rashid, A. and D.L. Rowell, 1988. Phosphorus sorption and release isotopically exchangeable and non exchangeable adsorbed phosphate in relation to soil properties. Pak. J. Soil Sci., 3: 17-20.

Sinegani, A.A.S. and S. Sedri, 2011. Effects of sterilization and temperature on the decrease kinetic of phosphorus bioavailability in two different soil types. J. Soil Sci. Plant Nutr., 11: 109-122. DOI: 10.4067/S0718-95162011000200010

Singh, R.K., M.B. Sengupta, N.N. Goswami and T.G. Sartry, 1990. Phosphate adsorption in salt affected soils at field capacity. J. Indian Soc. Soil Sci., 38: 434-437.

Soares, J.C.M., D. Gabriel, V. Folmer, G.R. Augusti and J.B.T. Rocha, 2011. High concentrations of glucose can activate or inhibit human erythrocyte aminolevulinate dehydratase in vitro depending exposure time. Am. J. Biochem. Biotechnol., 2: 180185. DOI: 10.3844/ajbbsp.2006.180.185

Soultanpur, P.N. and A.P. Schwab, 1977. A new soil test for simultaneous extraction of macro- and micro-nutrients in alkaline soils. Commn. Soil Sci. Plant Anal., 8: 195-207. DOI: 10.1080/00103627709366714

Toor, G.S., G.S. Bahl and A.C. Vig, 1997. Pattern of P availability in different soils as assessed by different adsorption equations. J. Ind. Soc. Soil Sci., 45: 719-723.

Torrent, J., 1995. Phosphate availability in calcareous vertisols and inceptisols in relation to fertilizer type and soil properties. Fert. Res., 40: 109-119. DOI: 10.1007/BF00750095

Zhang, H., J.L. Schroder, J.K. Fuhrman, N.T. Basta and D.E. Storm et al., 2005. Path and multiple regression analyses of phosphorus sorption capacity. Soil Sci. Soc. Am. J., 69: 96-106. DOI: 10.2136/sssaj2005.0096 